\title{
Adoption of Contract Farming and Precautionary Savings to Manage the Catastrophic Risk of Maize Farming: Evidence from Bangladesh
}

\author{
K M Mehedi Adnan $1,2, *(1)$, Liu Ying ${ }^{1,3, *}$, Swati Anindita Sarker ${ }^{4,5} \oplus$, Muhammad Hafeez ${ }^{6,7}$, \\ Amar Razzaq ${ }^{1}{ }^{(D)}$ and Muhammad Haseeb Raza ${ }^{1}$ \\ 1 College of Economics and Management, Huazhong Agricultural University, No.1 Shizishan Street, \\ Hongshan District, Wuhan 430070, China; amar.razzaq@hotmail.com (A.R.); \\ haseebrizvi00@yahoo.com (M.H.R.) \\ 2 Department of Agricultural Finance \& Banking, Sylhet Agricultural University, Sylhet-3100, Bangladesh \\ 3 Hubei Collaborative Innovation Center for Grain Industry, Yangtze University, Jingzhou 434025, China \\ 4 School of Economics and Management, University of Chinese Academy of Sciences, Beijing 100101, China; \\ aninditaswati@mails.ucas.edu.cn \\ 5 Department of Agricultural Economics, EXIM Bank Agricultural University Bangladesh, \\ Chapainawabganj 6300, Bangladesh \\ 6 School of Economics and Management, Beijing University of Posts and Telecommunications, No 10, \\ Xitucheng Road, Beijing 100876,China; hafeez_86@hotmail.com \\ 7 The Center of Industrial Economics and Green Development, Beijing University of Posts and \\ Telecommunications, No 10 Xitucheng Road, Beijing 100876, China \\ * Correspondence: mehediadnan@webmail.hzau.edu.cn or mehedi_adnan@yahoo.com (K.M.M.A.); \\ liuying@mail.hzau.edu.cn (L.Y.)
}

Received: 24 October 2018; Accepted: 18 December 2018; Published: 21 December 2018

\begin{abstract}
Agricultural production faces several types of risk, and risk management tools vary by place, season, and crop type. Most farmers use multiple risk-minimizing tools to reduce the effects of various hazards. However, previous research has overlooked the potential connections between different risk management tool utilization decisions. This study examines farmers' decisions of adopting risk management tools (contract farming and precautionary savings) and investigates the impacts of various factors on farmers' risk management decisions by using bivariate and multinomial probit models. The study was carried out in four different agro-ecological regions of Bangladesh with 350 farmers chosen through multistage stratified random sampling procedures. The findings revealed that the farmers' decisions towards adopting risk management tools are correlated, and the adoption of one risk management tool may induce farmers to adopt other risk management tools at that time. Moreover, the results revealed that age, education, income, and land ownership are the major factors affecting the adoption of risk management tools, and most farmers are risk-averse in nature. Both models provide interpretation and information for the development of a better understanding of the current situation of rural farm households, which may serve as a platform for policymakers who are anticipating appropriate risk management tools for the farmers.
\end{abstract}

Keywords: risk management tools; contract farming; precautionary savings; probit model; Bangladesh

\section{Introduction}

Risks and uncertainties are closely related to agricultural activities due to the uncertain economic and biophysical circumstances according to which farming operates [1]. In agriculture, risk and 
uncertainty are inseparable. Risk is imperfect knowledge where the probability of possible outcomes is known, and uncertainty exists when the probability is unknown. Uncertainty can be defined as inadequate information whereas risk implies unfavorable consequences to the economy or some adversity or losses which have negative effects on an individual's well-being [2]. Farming is a risky business because forces which are beyond the farmer's control affect the profitability of farming [3]. Risk, uncertainty, and agricultural production are inextricably related to income (variable returns) and have consequences for decision making in a specific time period [4]. Risk and uncertainty are typical features of agricultural production [5] which can harm production and cause extensive losses [6]. In farming, it is therefore important to be aware of risks, uncertainties, and the available options for mitigating these conditions [7]. Examples of risks and uncertainties include variations in frequency and intensity of rainfall, temperature fluctuations, crop diseases, and more. The prevalence of these risks makes the agriculture sector more risk-prone than other industries [8], and also affects other sectors of the economy [9]. In agriculture, the five most significant risk sources are production risks, marketing risks, legal risks, financial risks, and human resource risks [10,11]. Several types of risk management (RM) tools are available to farmers. The socioeconomic characteristics, losses by natural calamities, and perceptions of risk and risk attitudes of the farmer are considered to be important factors in the making of RM decisions [7,12]. Moreover, the relationships among various RM tools are also important considerations, as farmers commonly adopt multiple RM tools across a given time span [13]. The common risk-reducing strategies include crop diversification, off-farm and on-farm diversification, forward hedging, contract farming, crop insurance, and precautionary savings, each of which has been used by farmers in Bangladesh for managing the risks and uncertainties of agriculture.

Bangladesh, which is the focus of this study, is one of the countries that is most affected by natural calamities, which have previously caused massive damage to its agricultural sector. Bangladesh is an agro-based economy in which agriculture contributes $14.2 \%$ to overall GDP and employs $48 \%$ of the country's total workforce, including almost $65 \%$ of the rural population [14,15]. Agriculture sector in Bangladesh has experienced serious challenges from various catastrophic events. Hence, an adaption of RM tools in agriculture for reducing the effects of catastrophic impacts is an effective and necessary measure to protect the livelihoods of farmers. Most Bangladeshi farmers usually adopt one or more $\mathrm{RM}$ tools to protect against losses. Contract farming and precautionary savings are the most popular RM tools in Bangladesh.

Contract farming involves coordinating the production and supply of agricultural and horticultural products between sellers and buyers [16]. Contracts may differ based on existing circumstances, but generally, the amount and price of the product are specified [17]. Risk sharing is the most common reason to establish the contract [18]. A predetermined price provides a chance to reduce maximum risk in contract farming [19]. When contract farming is competently organized and well managed, it lessens risk and uncertainty, in contrast to purchasing and selling at open markets [20,21]. Some researchers have also studied collective economic organizations that share risk and mitigate moral hazard, comparing them with the relative performance of contracts, and found that contracts are attractive alternatives to risk sharing [22].

Precautionary saving is a self-insuring strategy for risk reduction used by farmers [12]. Precautionary savings include accumulation of liquid, semi-liquid and fixed assets, as well as assets in the form of hard cash, crop or yield inventories, livestock, farming tools, farming equipment, and additional useful assets $[23,24]$. Generally, these are extensively used by small farmers as ex-ante shock absorbing tools [25]. Additionally, age, training or education, the size of the household, earnings, and microcredit are all noteworthy factors which respectively determine farmers' attitudes towards risks handling [26-28].

The maize market in Bangladesh has enormous potential as a subsistence and cash crop, especially for small farmers [26,29]. The estimated maize area and production level are projected to increase to 448,000 hectors and 3.54 million metric tons (MMT) respectively in the 2018-2019 period. In 2018-2019, the total consumption of maize is predicted to rise to 4.4 MMT [30]. The demand for maize has grown 
in the poultry and fishery sectors as well as human food sectors [31,32]. As maize contributes $60 \%$ of the animal feed, it is estimated that in 2020 feed demand in the poultry sector alone will be 6.5 MMT, and maize will account for 3.9 MMT [30]. Also, in Bangladesh, the nutritional requirements of the increasing population are not being met by the traditional crops, which include rice and wheat. This has led to a widespread turn away from traditional rice-rice and rice-wheat cropping systems and toward rice-maize systems [33], however, natural calamities reduce the profit as well as the attraction of maize production among farmers. It is important to understand the RM strategies of maize for farmers as well as for policymakers. An understanding of farm characteristics, risk attitudes, risk perceptions, and RM usage policies is crucial to fill the demand gap for maize and enable sustainable income for farmers. Therefore, the prime concern of study is to elaborate the information related to the RM strategies of farmers, especially the participation in contract farming and adoption of precautionary savings, and their behaviors. Thus, the main objectives of this study are: (1) evaluation of the impact of farm and farm characteristics, farmers' risk perceptions, and their risk attitude on their decisions to adopt the two RM strategies; (2) to investigate the linkage between farmers' decisions for adopting the two RM strategies.

This study also reveals that both RM strategies have a positive impact and most of the farmers are risk averters. This infers that strategies cannot be evaluated solely in terms of expected output, but risk must be considered. Lastly, the findings of risk perceptions and attitudes of farmers regarding RM strategies from bivariate and the multinomial analyses enables us to formulate better policies for agricultural development.

\section{Literature Review and Theoretical Background}

In this section, some related literature about the different causes of agricultural risk and different factors affecting the decisions of farmers for adopting the risk management (RM) strategies for reducing risk at the farm level are presented.

Hardaker et al. [2] made a distinction between two important forms of risk in the field of agriculture; firstly, the risk in business posed by the risk in production, and secondly, the financial risk that remains a result of various systems of funding to different farm businesses. As stated by Drollette [6], in the agriculture sector, production risk is the most important risk. But, according to Harwood et al., the climatic risk is paramount among all production risks for developing countries [34]. In the field of agriculture, along with the features of the farm and risk situation, RM strategies differ from one another, as presented by Hope and Lingard [35]. The choices and communications associated among the farmers are independent of risk attitudes, risk perceptions, and purposes, in addition to the existing resources [36-38]. A group of researchers similarly found that farmers risk choices differ significantly with their age [25,39], literacy level [40], earnings [41], farming practice [42], farmstead size [43], and land proprietorship status [44].

Another group of researchers discussed the influencing factors of a single adoption of an RM tool, rather simultaneous adoption, and their linkages [45]. The implementation of the RM strategies depends on various factors, including irregular conditions of weather, inconsistency in output and input prices, rapidly advancing technology, and farmer indebtedness. Besides these factors, features of farms, farm families, risk observations, and attitudes of farmers considerably affect farmers risk management choices [46]. The bivariate and multinomial probit models calculated the impacts of different risk managing approaches which are concurrently accessible and usable to the growers $[1,13,23,47]$. In the existing literature, the theoretical causes and effects of farmer's choices about RM are properly acknowledged. However, the simultaneous adoption of multiple risk-coping strategies, i.e., contract farming and precautionary savings, are less studied. Most importantly, a few existing available studies were conducted for different economies, except for Bangladesh. To fill this gap, we investigate the simultaneous adoption of two RM tools among maize cultivators in Bangladesh by considering the bivariate and multinomial probit models. We also measure the influence of several issues on the implementation of these two tools for risk reduction. 
The relationship between different risks and associated RM tools are presented in Figure 1.

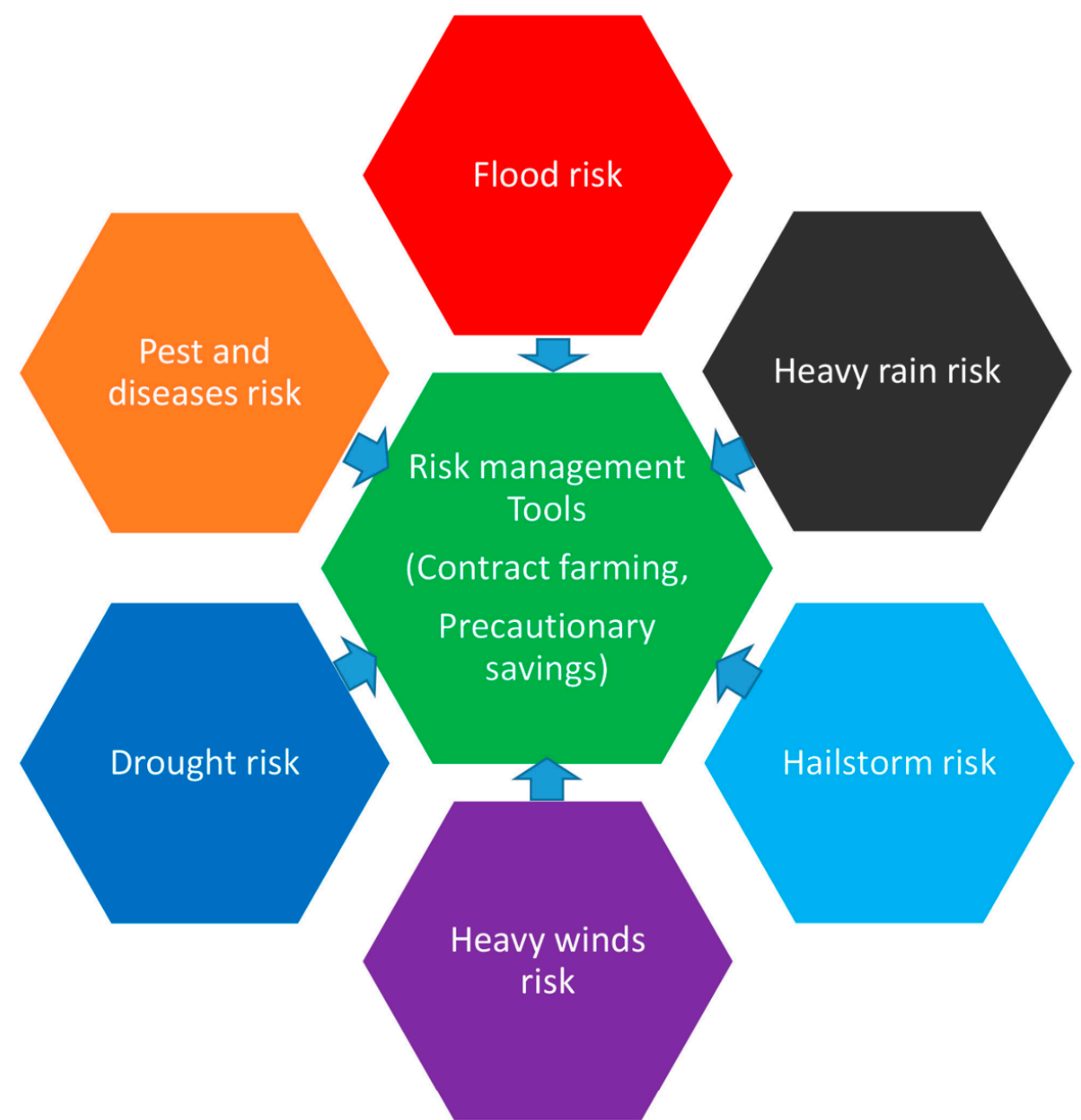

RM tools associated with different risks

\begin{tabular}{|l|l|l|l|l|l|l|}
\hline $\begin{array}{c}\text { Different } \\
\text { types } \\
\text { risks } \\
\begin{array}{c}\text { Risk } \\
\text { magement } \\
\text { tools }\end{array}\end{array}$ & $\begin{array}{c}\text { Risk of } \\
\text { floods }\end{array}$ & $\begin{array}{c}\text { Risk of pest } \\
\text { and diseases }\end{array}$ & $\begin{array}{c}\text { Risk of } \\
\text { drought }\end{array}$ & $\begin{array}{c}\text { Risk of } \\
\text { heavy rains }\end{array}$ & $\begin{array}{c}\text { Risk of } \\
\text { heavy winds }\end{array}$ & $\begin{array}{c}\text { Risk of } \\
\text { hailstorm }\end{array}$ \\
\hline $\begin{array}{l}\text { Contract } \\
\text { farming }\end{array}$ & & & & & & \\
\hline $\begin{array}{l}\text { Precautionary } \\
\text { savings }\end{array}$ & & & & & & \\
\hline
\end{tabular}

\begin{tabular}{|l|l|l|l|}
\hline Extreme & High & Medium & Low \\
\hline
\end{tabular}

\section{Severity of different risks to adopt RM tools}

Figure 1. Infographic presentation of different risks and RM strategies.

\section{Materials and Methods}

\subsection{Study Area and Sampling}

The current research mainly emphasizes contract farming adoption and precautionary savings for a reduction in farming risks among maize cultivators in selected areas of Bangladesh. Primary data for the study was collected from May-July 2018 from four different agro-ecological regions of Bangladesh 
by a farm-survey (Figure 2). The multistage stratified random sampling procedure was used to collect data from 350 farm households in 35 villages. In Bangladesh, most farmers do not keep data record properly, so most of the data were collected from the farmers as a method of declaration. Data were collected from 7 villages in the Manikgonj district, signifying wet agro-ecology; 10 villages of the Dinajpur district, signifying dry agro-ecology; 8 villages of the district of Comilla, signifying wet agro-ecology; and 10 villages from Bogra district, signifying semi-dry agro-ecology. The interview schedule contained all related data concerning socioeconomic aspects of the farming households, sources of income, farmer's perceptions regarding various sources of risk for the maize crop, and indicators for assessing risk attitudes of farmers and risk perceptions together with an apparent arrangement of RM strategies applied for maize production.

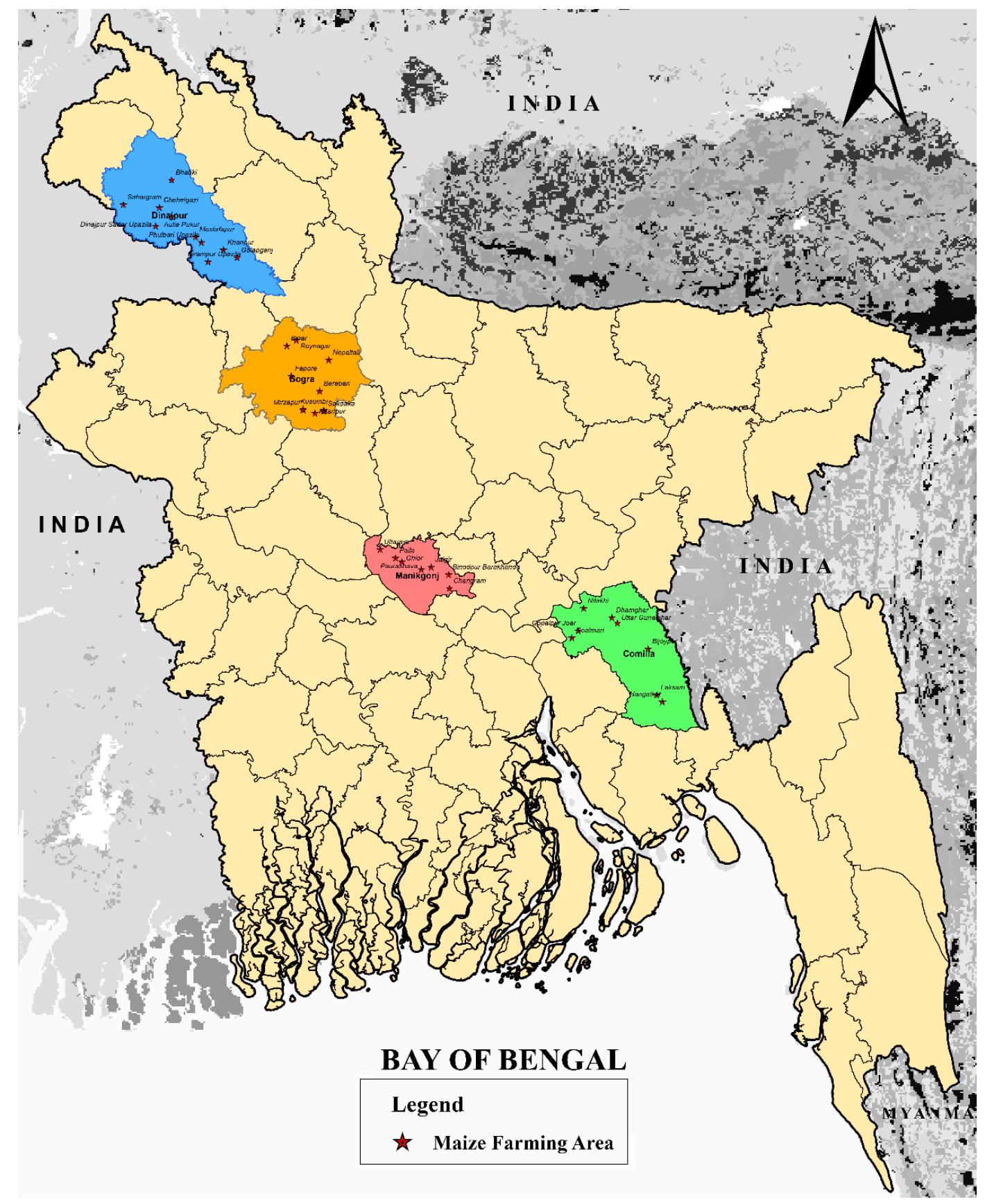

Figure 2. Study area (Using GIS data). 


\subsection{Empirical Specification}

Contract farming and precautionary savings are two RM adoption choices and are dependent variables for analysis. Because of frequent adopting of tools by maize growers, these two tools were selected in our sampling. Along with these tools, four apparent arrangements of these strategies were used as the foundations of the dependent variables for the multinomial probit assessment. The four probable arrangements which can be adopted by maize growers are: (1) Not using a risk management tool, i.e., the farmer didn't implement contract farming or precautionary savings; (2) use of only contract farming; (3) use of only precautionary savings, and (4) usage of both RM tools concurrently. Table 1 includes the elaborated percentages of maize producers with various combinations of RM tools. Table 1 indicates that most farmers have not used risk management tools $(32.28 \%)$, and the second largest category was the use of contract farming $(28.29 \%)$. Combination 4 (both the RM tools combined) was used by $24.29 \%$ of the respondents, whereas $15.14 \%$ farmers used only precautionary savings.

Table 1. Different combinations of RM tools adopted by farmers.

\begin{tabular}{lcc}
\hline \multicolumn{1}{c}{ RM Tools } & Numbers of Respondent & Proportion (\%) \\
\hline No risk management tools used & 113 & 32.28 \\
Only contract farming used & 99 & 28.29 \\
Only precautionary savings used & 53 & 15.14 \\
Both tools used & 85 & 24.29 \\
\hline
\end{tabular}

Source: Author calculation, 2018.

\subsection{Variables and Their Descriptions}

\subsubsection{Dependent Variables}

\section{Contract Farming}

Contract farming involves agricultural production carried out on the basis of an agreement between the buyer and farm producers which establishes the conditions for the production and marketing of a farm product or products. Typically, the farmer agrees to provide specified quantities of a specific agricultural product. These should meet the quality standards of the purchaser and be supplied at the time determined by the purchaser. In turn, the buyer commits to purchase the product and, in some cases, to support production through, for example, the supply of farm inputs, land preparation, and the provision of technical advice. Contract farming provides a better linkage among production, processing, and marketing, and all actors in the value chain-farmers, retailers, custom hire machine operators, retailers, traders, processing companies, and bankers—are key stakeholders. Among the various uses of contract farming, its important role in risk management is considered for the study, and included in the analysis as 1 if the farmer uses contract farming only for the purpose of risk management, and 0 otherwise.

\section{Precautionary Savings}

Increased uncertainty regarding future income generates the so-called precautionary savings. The precautionary motive of farmers to delay consumption and save in the current period arises due to the underdevelopment of insurance markets. Accordingly, individuals will not be able to insure against bad production and economic circumstances in the future. To avoid adverse effects of future income fluctuations and retain a smooth path of consumption, they set aside a precautionary reserve, called precautionary savings. Precautionary savings are widely used as ex-post shock absorbing mechanisms, mostly by small farmers. It is included in the analysis as 1 if the farmer is using it as an ex-post risk coping tool only to reduce the negative shocks to their farm incomes arising from adverse weather conditions, and 0 otherwise. 


\subsubsection{Independent Variables}

\section{Socio-Economic and Demographic Factors}

The demographic and socio-economic aspects reflected through the paper are the respondent's age, education level, experience in farming, their monthly family income, size of family, and household farmstead size, together with the type of land in possession. Education, age, and experience of farming of the family are continuous variables; symbolizing the count of years, the income of the household is its total earnings in a month from off-farm and farm resources in Bangladeshi Taka (BDT). The number of household family members was used to measure the size of the family, the number of hectares operated by the household was used to measure the size of the farm, and the status of ownership of the land is scored as 1 if the family owns the farming property, and 0 if otherwise.

\section{Risk Perception}

The catastrophic risks can be classified into six categories. These are stated as: (i) Flood risk, (ii) heavy rain risk, (iii) pest and disease risk, (iv) drought risk, (v) heavy wind risk, and (vi) hailstorm risk. Farmers were asked to score the occurrence and harshness of each risk source on a Likert scale (LS), from 1 (very low) to 5 (very high), in order to observe how significant each source is considered in terms of its potential impact on their farming enterprises. Risk factor (RF) can be obtained if the risks are ranked and created on the production of livelihood $(\mathrm{P})$ and the consequence (C). A risk matrix $[48,49]$ was prepared to combine the scores. If RF is from $2-5$, it is classified as low, and if the $\mathrm{RF}$ is between $6-10$, it is considered to be high. The variables of risk perception from the analysis are considered to be 1 if the farmer realizes that the disaster risk is a high-risk source for their farm, and otherwise it is scored as 0 .

\section{Risk Attitude}

The risk attitudes of the farmers, based on the Equally Likely Certainty Equivalent (ELCE) model, is measured through utility function. The ELCE model [2] is the most commonly used method for eliciting utility. Certainty equivalents (CEs) are derived for a sequence of risky outcomes and matched with utility values [50]. For example, if the farmer has been asked to specify the economic value of an outcome between two risky results in BDT (total income of the household in Bangladeshi Taka, say 30,000 BDT and $0 \mathrm{BDT}$, with identical possibility), let us assume the response was 21,200 BDT. If the farmer was requested again to specify the economic value of a sure outcome that makes him remain same to both the risky outcomes of 21,200 BDT and 0 BDT with equal possibility, assume, the reply was 11,600 BDT. This procedure was sustained until an adequate amount of data points had been accumulated. For the residual half of the income circulation, the respondent had been asked to define the economic worth of a stated result that has been viewed the same among 21,200 BDT and 30,000 BDT, each having a 0.5 probability. Plenty of CE equivalent results were found and coincided among their corresponding utility scores following this process. The utility scores attached to the lesser bound income (BDT 0) and to the upper bound income (30,000 BDT) are 0 and 1, respectively. The response of the farmer for BDT 21,200 was his estimated CE for payouts that would be uncertain out of 30,000 BDT and 0 BDT with same probabilities (0.5 each), and the CE utility value is calculated as:

$$
\mathrm{U}(21,200)=0.5 \mathrm{u}(0)+0.5 \mathrm{u}(30,000)=0.5(0)+0.5(1)=0.50
$$

In a similar way, the utility values for each calculation of CE points are computed and displayed in Table 2. 
Table 2. Example to elicit certainty equivalents (CE) and compute utility values (UV).

\begin{tabular}{|c|c|c|}
\hline Stage & Elicited CE & Utility Calculation (UC) \\
\hline & Pay/income scale & $U(0)=0$ and $U(30,000)=1$ \\
\hline 1 & $(21,200 ; 1.0) \sim(0,30,000 ; 0.5,0.5)$ & $\mathrm{U}(21,200)=0.5 \mathrm{u}(0)+0.5 \mathrm{u}(30,000)=0.5$ \\
\hline 2 & $(11,600 ; 1.0) \sim(0,21,200 ; 0.5,0.5)$ & $U(11,600)=0.5 u(0)+0.5 u(21,200)=0.25$ \\
\hline 3 & $(7000 ; 1.0) \sim(0,11,600 ; 0.5,0.5)$ & $\mathrm{U}(7000)=0.5 \mathrm{u}(0)+0.5 \mathrm{u}(11,600)=0.125$ \\
\hline 4 & $(4000 ; 1.0) \sim(0,7000 ; 0.5,0.5)$ & $\mathrm{U}(4000)=0.5 \mathrm{u}(0)+0.5 \mathrm{u}(7000)=0.0625$ \\
\hline 5 & $(28,000 ; 1.0) \sim(30,000,21,200 ; 0.5,0.5)$ & $\mathrm{U}(28,000)=0.5 \mathrm{u}(30,000)+(0.5 \mathrm{u}(21,200)=0.75$ \\
\hline 6 & $(33,500 ; 1.0) \sim(30,000,28,000 ; 0.5,0.5)$ & $\mathrm{U}(33,500)=0.5 \mathrm{u}(30,000)+(0.5 \mathrm{u}(28,000)=0.875$ \\
\hline 7 & $(38,000 ; 1.0) \sim(30,000,33,500 ; 0.5,0.5)$ & $\mathrm{U}(38,000)=0.5 \mathrm{u}(30,000)+(0.5 \mathrm{u}(33,500)=0.938$ \\
\hline
\end{tabular}

Subsequent to the derivation of numerous CEs and comparison of the equivalents with the values of utility, a cubic utility function was used for estimating the utility of every farmer. The cubic utility function equation is as follows:

$$
u(w)=\alpha_{1}+\alpha_{2} w+\alpha_{3} w^{2}+\alpha_{4} w^{3}
$$

Risk aversion, risk perception, and risk attitudes are all clear parts of the cubic utility function [50]. An ordinal scale is usually used for measuring utility; however, to define absolute risk aversion, it can be described as an ordinal scale having a utility function on it which can be transformed by changing its shape into a calculable measure of risk aversion [51,52]. The absolute aversion to risk can be mathematically defined using the equation:

$$
r_{a}(W)=U^{1}(W) U^{2}(W)
$$

In Equation (3), $r_{a}(W)$ can be defined as a coefficient of absolute risk aversion, and $U^{1}, U^{2}$ are $1^{\text {st }}$ and $2^{\text {nd }}$ order derivatives of capital $(\mathrm{W})$, respectively. To analyze the equation, the outcome was replaced for capital or wealth [53]. The $\mathrm{r}_{\mathrm{a}}(\mathrm{W})$ was found to be optimistic, negative, or zero, depending on certain parameters. Firstly, in the case where the individual is risk-averse, the result is positive; otherwise, if the farmer desires risk, then it is negative. Finally, if the farmer is unaffected by the risk, then the result is zero. The analysis expresses the risk attitudes of the growers, denoting the representation as 1 when an individual reflects risk-averseness and 0 in any other case. Following a similar methodology, a regression analysis was carried out independently on 350 farmers for the purpose of calculating the risk aversion coefficient to additionally analyze the risk attitudes shown by maize cultivators in the field.

\section{Analytical Models}

\subsection{Bivariate Probit Model}

Evaluating the perception of risk and the risk attitudes of the growers for different sources of risk related to the production of maize, a probit model has been used due to binary nature of dependent variable for assessing the influence of different on farmers' decision-making regarding adoption of contract farming and precautionary savings. An individual probit model was used where the dependent factors (contract farming and precautionary savings) are dichotomous in nature. Similarly, a bivariate probit model which calculates the probability of a concurrent connection between the growers' decision for adopting contract farming and precautionary savings can be described as follows:

$$
Y_{i j}=X_{i j} \beta_{j}+\epsilon_{i j}
$$

In Equation (4), $Y_{i j}(j=1, \ldots m)$ reflects the options for risk supervision, i.e., contract farming and precautionary savings accepted by the $i^{\text {th }}$ farmer $(i=1, \ldots, n), X_{i j}=1 \times k$ reflects the vector for the experiential factors that distress the decision for such adoption for $\mathrm{RM}$, and $\beta_{j}=\mathrm{k} \times 1$ reflects 
the vector of constraints that are yet to be calculated, and $\epsilon_{i j}=$ ignored error term [54]. In the relation stated, each $Y_{j}=$ bivariate factor was calculated by:

$$
\begin{aligned}
& Y_{1}^{*}=\alpha_{1}+X \beta_{1}+\epsilon_{1} \\
& Y_{2}^{*}=\alpha_{2}+X \beta_{2}+\epsilon_{2}
\end{aligned}
$$

In Equations (5) and (6), $Y_{1}{ }^{*}$ and $Y_{2}{ }^{*}$ are the suppressed variables that represent each decision for implementation of risk strategies. For example, $Y j=1$ if the score is greater than 0 , otherwise it will be 0 .

\subsection{Multinomial Probit Model}

In the multinomial probit regression, the choice set is made up of all possible combinations of risk management tools instead of just the risk management alternatives by themselves [13]. With two alternatives for RM in the study, a maize grower would choose to adopt from four possible combinations. Given the set of choices, a multinomial probit model can be identified as follows:

$$
Y_{i}=i \beta+\epsilon_{i} \epsilon_{i} \sim \operatorname{MVN}\left(0, \sum\right)
$$

In Equation (7), Yi represents the tool combination for the RM. Where, $Y_{i}=1, \ldots, m$; that $i^{\text {th }}$ producer $(\mathrm{i}=1, \ldots, \mathrm{n})$ chooses, and $X_{\mathrm{i}}=1 \times \mathrm{k}$ vector of the defined variable that affects the maize grower's chosen RM combination, $\beta=\mathrm{k} \times 1$ vector parameters that are yet to be calculated, and $\epsilon_{\mathrm{i}}=$ the undefined error term. The error term is set to be multivariate and normal with the mean as 0 and an inconsistency covariance matrix $\sum$. Farm and household features including farming experience, education, household size, age, total revenue, land possession status, size of the maize farm, farmers' perception of risk sources (heavy rainfall, risk from flood, pest and diseases, heavy wind, hailstorm, and risk of drought), and the farmers' risk aversion are the independent variables.

\section{Results of the Study}

\subsection{Summary Statisitics of Variables Used in Empirical Models}

Here, Table 3 represents the descriptive statistics of several variables applied in the investigation. Most farmers designated the heavy rainfall or hailstorm risk, heavy wind risk, and pest or infection risk as important risk sources, respectively. To escape any kind of undesirable circumstances originating from various types of risk sources of maize production, almost $56 \%$ of farmers were growing maize through contract farming arrangements, whereas less than half of the growers used precautionary savings as an RM tool. $76 \%$ of Bangladeshi farmers demonstrated risk aversion from the sampled set of the selected area. These outcomes are consistent with past research including Lucas et al. [44], Dadzie et al. [25], and Raza et al. [1], who similarly elaborated that the majority of farmers from the sample set are risk-averse naturally. 
Table 3. Descriptive statistics of variables used in empirical models in the study.

\begin{tabular}{|c|c|c|c|}
\hline Variables & Explanation & Mean & Standard Deviation (SD) \\
\hline \multicolumn{4}{|l|}{ Dependent variables } \\
\hline Contract farming (CF) & 1 , if doing contract farming and 0 , otherwise & 0.56 & 0.51 \\
\hline \multicolumn{4}{|l|}{ Independent variables } \\
\hline \multicolumn{4}{|c|}{ Farm and socioeconomic characteristics } \\
\hline Education of farmer & Number of years of schooling & 4.05 & 6.01 \\
\hline Farming year & Number of farming experience years & 18.32 & 14.98 \\
\hline Household income & Monthly family income (farm and off-farm) in BDT & $24,535.54$ & $14,999.35$ \\
\hline Family size & No. of family fellows & 5.34 & 2.37 \\
\hline Farm size & Total farmstead area in acres & 6.04 & 2.39 \\
\hline Heavy rain risk & 1 , risk factor score $>5$ and 0 , otherwise & 0.71 & 0.44 \\
\hline Pest and disease risk & 1 , risk factor score $>5$ and 0 , otherwise & 0.78 & 0.43 \\
\hline Drought risk & 1 , risk factor score $>5$ and 0 , otherwise & 0.40 & 0.49 \\
\hline Heavy wind risk & 1 , risk factor score $>5$ and 0 , otherwise & 0.77 & 0.43 \\
\hline Hailstorm risk & 1 , risk factor score $>5$ and 0 , otherwise & 0.47 & 0.50 \\
\hline \multicolumn{4}{|l|}{ Risk attitude } \\
\hline Risk Aversion & 1 , if the farmer shows aversive attitude to the risk and 0 , otherwise & 0.76 & 0.44 \\
\hline Sample size & & & 350 \\
\hline
\end{tabular}

Source: Survey data, 2018.

\subsection{Results from Probit Models}

The estimated parameters from the bivariate and individual probit models are presented in Table 4 . The bivariate probit and individual probit models were mainly applied to conduct the analysis and for comparison purposes based on the maximum likelihood method. For the two adoption choices for RM, the coefficient of correlation is the paired association among the error terms of the two equations in the bivariate probit model to infer the selection of probit models from either bivariate or individual probit models [55]. The correlation coefficient is positive and statistically significant, affirming the bivariate probit method rather than the two independent probit models. The positive correlation coefficient further specifies that the choice to implement one specific RM approach suggests that the alternative approach will be accepted [55]. The likelihood ratio test of $\rho_{\mathrm{kj}}$ (3.19067) and Wald $\chi^{2}{ }_{(28)}$ test (139.87) also infers the bivariate probit, and not the independent probit models. The hypothesis $\mathrm{H}_{0}$ of conjoint nullity of $\rho_{\mathrm{kj}}$ can be rejected.

Table 4. Results of individual and bivariate probit models.

\begin{tabular}{|c|c|c|c|c|}
\hline \multirow{2}{*}{ Independent Variables } & \multicolumn{2}{|c|}{ Bivariate Probit model } & \multicolumn{2}{|c|}{ Individual Probit Model } \\
\hline & Contract Farming & Precautionary Savings & Contract Farming & Precautionary Savings \\
\hline \multicolumn{5}{|c|}{ Farm and socioeconomic characteristics } \\
\hline Age of farmer & $\begin{array}{l}0.0283^{* *} \\
(0.0116)\end{array}$ & $\begin{array}{c}-0.0289 * * \\
(0.0126)\end{array}$ & $\begin{array}{l}0.0293 * * \\
(0.0117)\end{array}$ & $\begin{array}{c}-0.0287^{* *} \\
(0.0126)\end{array}$ \\
\hline Education of farmer & $\begin{array}{l}0.0317^{*} \\
(0.0187)\end{array}$ & $\begin{array}{c}-0.05511^{* * *} \\
(0.0189)\end{array}$ & $\begin{array}{l}0.0319 * \\
(0.0184)\end{array}$ & $\begin{array}{c}-0.0580^{* * * *} \\
(0.0191)\end{array}$ \\
\hline Farming year & $\begin{array}{c}-0.0327^{* * * *} \\
(0.0109)\end{array}$ & $\begin{array}{c}0.0107 \\
(0.0119)\end{array}$ & $\begin{array}{c}-0.03311^{* * *} \\
(0.0110)\end{array}$ & $\begin{array}{c}0.0099 \\
(0.0119)\end{array}$ \\
\hline Household income & $\begin{array}{l}0.00001 * * * \\
(0.0000007)\end{array}$ & $\begin{array}{l}0.00003 * * * \\
(0.000001)\end{array}$ & $\begin{array}{l}0.00001^{* * *} \\
(0.0000007)\end{array}$ & $\begin{array}{l}0.00003^{* * *} \\
(0.000001)\end{array}$ \\
\hline Family size & $\begin{array}{c}0.0151 \\
(0.0241)\end{array}$ & $\begin{array}{l}-0.0143 \\
(0.0257)\end{array}$ & $\begin{array}{c}0.0150 \\
(0.0242)\end{array}$ & $\begin{array}{l}-0.0138 \\
(0.0254)\end{array}$ \\
\hline
\end{tabular}


Table 4. Cont.

\begin{tabular}{|c|c|c|c|c|}
\hline \multirow{2}{*}{ Independent Variables } & \multicolumn{2}{|c|}{ Bivariate Probit model } & \multicolumn{2}{|c|}{ Individual Probit Model } \\
\hline & Contract Farming & Precautionary Savings & Contract Farming & Precautionary Savings \\
\hline Farm size & $\begin{array}{c}-0.01177^{*} \\
(0.0666)\end{array}$ & $\begin{array}{c}0.0807 \\
(0.0621)\end{array}$ & $\begin{array}{c}-0.01116^{*} \\
(0.0664)\end{array}$ & $\begin{array}{c}0.0846 \\
(0.0621)\end{array}$ \\
\hline Land ownership & $\begin{array}{c}0.7873^{* * *} \\
(0.1799)\end{array}$ & $\begin{array}{c}0.6998 * * * \\
(0.1842)\end{array}$ & $\begin{array}{c}0.7769 * * * \\
(0.1796)\end{array}$ & $\begin{array}{c}0.6949 * * * \\
(0.1839)\end{array}$ \\
\hline \multicolumn{5}{|c|}{ Risk perceptions } \\
\hline Flood risk & $\begin{array}{c}0.2451 \\
(0.1873)\end{array}$ & $\begin{array}{c}0.6621 \\
(0.1907)\end{array}$ & $\begin{array}{c}0.2461 \\
(0.1877)\end{array}$ & $\begin{array}{c}0.6583 \\
(0.1909)\end{array}$ \\
\hline Heavy rain risk & $\begin{array}{l}-0.1387 \\
(0.1857)\end{array}$ & $\begin{array}{c}0.4527 \\
(0.1863)\end{array}$ & $\begin{array}{l}-0.1415 \\
(0.1847)\end{array}$ & $\begin{array}{c}0.4393 \\
(0.1853)\end{array}$ \\
\hline Pest and disease risk & $\begin{array}{c}0.2021 \\
(0.1847)\end{array}$ & $\begin{array}{l}-0.5857 \\
(0.1922)\end{array}$ & $\begin{array}{c}0.2029 \\
(0.1841)\end{array}$ & $\begin{array}{l}-0.5855 \\
(0.1919)\end{array}$ \\
\hline Drought risk & $\begin{array}{c}0.1643 \\
(0.2835)\end{array}$ & $\begin{array}{c}0.0309 \\
(0.2560)\end{array}$ & $\begin{array}{c}0.1489 \\
(0.2829)\end{array}$ & $\begin{array}{c}0.0219 \\
(0.2569)\end{array}$ \\
\hline Heavy wind risk & $\begin{array}{c}0.2019 \\
(0.1799)\end{array}$ & $\begin{array}{l}-0.5799 \\
(0.1889)\end{array}$ & $\begin{array}{c}0.2017 \\
(0.1803)\end{array}$ & $\begin{array}{l}-0.5801 \\
(0.1807)\end{array}$ \\
\hline Hailstorm risk & $\begin{array}{l}-0.0141 \\
(0.2557)\end{array}$ & $\begin{array}{c}0.1853 \\
(0.2389)\end{array}$ & $\begin{array}{l}-0.0059 \\
(0.2559)\end{array}$ & $\begin{array}{c}0.1933 \\
(0.2398)\end{array}$ \\
\hline \multicolumn{5}{|c|}{ Risk attitude } \\
\hline Risk aversion & $\begin{array}{c}0.9087 \\
(0.2267)\end{array}$ & $\begin{array}{c}1.0123 \\
(0.2331)\end{array}$ & $\begin{array}{c}0.8998 \\
(0.2259)\end{array}$ & $\begin{array}{c}1.0731 \\
(0.2346)\end{array}$ \\
\hline Log-likelihood value & -351.0135 & & -169.1571 & -179.5213 \\
\hline Wald $\chi^{2}$ & $139.87^{* * *}$ & & & \\
\hline LR test ${ }_{p k j}$ & $3.19067^{*}$ & & & \\
\hline LR test $\chi^{2}(14)$ & & & $105.79^{* * *}$ & $78.09 * * *$ \\
\hline Pscudo- $R^{2}$ & & & 0.2177 & 0.1801 \\
\hline Correlation coefficient & $0.149^{* * *}$ & & & \\
\hline Total Sample size & 350 & & & \\
\hline
\end{tabular}

Numbers in parenthesis are normalized standard errors. ${ }^{*}{ }^{* *}$, and ${ }^{* * *}$ represent respectively statistical significance at 10,5 , and 1 percent level.

\subsubsection{Results of Individual and Bivariate Probit Models}

Age, farming experience, education, farm size, monthly income, status of land ownership, and risk-averse habits of the household head are important variables affecting the adoption of contract farming. In this study, age has a positive effect on contract farming adoption. Older people may choose less risky investments by participating in the contract farming to avoid the negative impacts of unfavorable climate. Earlier studies establish mixed outcomes of age on farmer's choices to accept contract farming for managing farm level risk. For the age variable, the outcomes of our study are in agreement with Cahyadi et al. [56], Deressa et al. [57], and Wencong et al. [55], who similarly discovered a positive influence of age on implementation of contract farming, though Wainaina et al. [58] established a negative relationship between age and acceptance of contract farming. The effect of education is positively related to the adoption of contract farming. This may be because educated people can access more information and can identify the benefits of risk management tools. This is consistent with Tavernier and Onyango [59], Kouame [37], Wencong et al. [55], and Ashfaq et al. [60], who found a positive relationship between education and acceptance of contract farming as a RM tool. The result is inconsistent with Wainaina et al. [58], who noted a negative impact of education on contract farming. The coefficient of farming experience indicated a negative relationship between contract farming and farming experience. An experienced farmer tends to avoid the use of contract farming. More experienced farmers may have more information about how to deal with natural hazards, and this type of experience with climate change may influence a farmer to avoid contract farming as an RM tool. Another possible explanation may be the fact that more 
experienced farmers generally stick to the use of traditional tools and are less adoptive of modern tools. Wainaina et al. [58] similarly showed a negative influence of farming experience on farmer's choices of implementing contract farming to cope up with farm risk. However, Wencong et al. [55] stated a positive relationship between farming experience with farmer's choice of accepting contract farming for RM. The results show that farmers with high monthly income are more likely to practice contract farming. A higher income attracts the farmer to contract farming to generate more income and less risky investments. This result is in agreement with Wainaina et al. [58], but contrasts with Wencong et al. [55] and Rehima et al. [61]. However, it should be noted that the existence of reverse causality may bias our results. Contract farming also has the potential to increase farmers' incomes first, so they are more likely to participate further in contract farming [62]. In this study, land ownership has a positive effect on the adoption of contract farming. This may be because landlords find it easier to make decisions by themselves and tend to implement contract farming for the purpose of reducing the influences of adverse climate situations related to a tenant farmer's choices, which are associated with the owner's willpower. Moreover, Wencong et al. [55] claimed that owning a larger amount of land is a sign of taking a high capacity for risk, and vice versa. The results of this study suggest that people who do small-scale farming are more expected to adopt contract farming to cope with risks emerging from unfavorable climate situations. Furthermore, the outcome is dissimilar with Kouame [37], Fawole et al. [63], and Wencong et al. [55], conveying a positive relationship between farm size and the acceptance of contract farming for managing farm risks. Again, this result suggests that the existence of a reverse causal relationship between land and participation in contract farming may bias our estimates.

The impacts of farmer's perceptions of risk sources on their choices to implement contract farming differ between variables. Variables associated with risk of flooding are positively correlated and similar to the results of Wencong et al. [55], because Bangladesh often faces unexpected floods which wash away agricultural yields. To prevent extensive losses from crop production, farmers used contract farming to reduce the risk of heavy losses. Risk of heavy rains are surprisingly negatively correlated, which is in contrast with Wencong et al. [55]; it may be that most of the maize production was done in the winter season in Bangladesh, and average rainfall is low in this season. Risk perception about pests and diseases has a positive but insignificant effect on the farmer's decision of adopting contract farming as a risk management approach. Moreover, the risk observation of drought and heavy winds may encourage the adoption of contract farming. Drought may lead to significant crop yield losses resulting in a decline of net returns from crop production. Because winter season farmers face a scarcity of irrigation water in different regions, they may adopt contracts. Also, Bangladesh suffers from frequent cyclones and unfavorable climates which create heavy winds, and as a result maize kernels may fall before maturity, reducing yield or profit. Hailstorms also have a negative impact on contract farming and reduce yield and profit. The farmer's risk-averse behavior also encourages adoption of contract farming for minimizing risks. Kouame [37], Wainaina et al. [58], and Wencong et al. [55] also established a significant positive effect of risk-averse behavior with the choice of adopting contract farming. However, we note that farmers' risk perceptions are subjective indicators, and we may have also captured other constraints that affect their decision to participate in contract farming when measuring these risk perceptions. Therefore, we recommend that the baseline results be interpreted as a causal effect with caution.

The factors affecting the adoption of precautionary savings include age, education, monthly income, land ownership, flood risk perceptions, drought, heavy rainfall, hailstorms, and risk-averse behavior of farmers. Age is negatively correlated with precautionary savings. Older people bear more responsibility and have more family expenses, so they don't have enough money for savings. This result is consistent with Jensen and Pop [64], and Raza Ullah et al. [23]. They revealed that age has a negative effect on a farmer's adoption of precautionary savings. Mishra [65] conveyed that adoption of precautionary savings had a positive relationship with age. Farmers with more education are more expected to avoid adoption of precautionary savings for managing farming risks. A possible 
explanation for this situation may be the fact that educated farmers generally know more about markets and probable risks, so they are more aware of upcoming risks and thus do not need to save for natural hazards; rather they invest that money in other fields as a source of off-farm income. The outcome of the education factor is in agreement with Kouame [37] and Raza Ullah et al. [23], who established that literacy has a negative relationship with precautionary savings. However, Mishra [65] perceived a positive relationship between the education of the heads of the household and precautionary savings.

Deressa et al. [57] proposed a positive relationship with age and education on the decision of farmers to sell livestock when facing a risky situation. Higher household monthly earnings encourage farmers to invest their income into some assets (especially liquid assets), which are sellable upon need. Most farmers in the study raise animals that are exchangeable for money to cope with climate disasters, and may also do some off-farm work. The outcomes mentioned above also indicate how important farming experience and farm size are, as these factors insignificantly yet positively affect the decisions of farmers in implementing precautionary savings as RM tool. The larger farm size provides a bigger asset base and encourages the accumulation of assets in liquid form to managing variations in the incomes of their farms. Experience in farming similarly plays an important role in the choice of implementing RM approaches. The results reveal that farmers who have more experience tend to adopt the precautionary savings approach compared to a farmer who has less experience. In this study, land ownership has a positive effect on the adoption of precautionary savings. Probably, landlords discover it easier to save personally and tend to save some form of liquid assets to reduce the influences of climate situations. However, tenant farmers face difficulties in saving because of their small amount of farm resources and little income. These results are consistent with Kouame [37] but conflict with Raza Ullah et al. [23].

Farming risks rising from heavy rain, floods, and droughts might incite crop failure, severely affecting the farmers' livelihoods, for which cultivation is a principal source of earning and occupation. These sources of risk affect farmer's earnings and persuade them to invest in some liquid or semi-liquid resources that can be used as a buffer during difficult periods. Farmer's behaviors concerning risks likewise shape their decisions towards the adoption of precautionary savings as a tool for overcoming any environmental challenges. Since contract farming and precautionary savings are correlated, we exercise the same level of caution while interpreting the results of the precautionary savings model as causal effects.

The outcomes discussed above are the parameter estimations of the bivariate probit model. In contrast, parameter estimates are also provided for the individual probit model. For both approaches, the symbols and consequence effect levels are equally alike. However, the bivariate probit approach helps the calculation of the conditional marginal effects (i.e., marginal effects conditional on the adoption of other RM tools), whereas the individual probit method does not permit such estimation [13].

\subsubsection{Marginal Effects of the Estimations}

Marginal effects highlight the discrete or instantaneous rate changes from odd ratios $[1,13,55]$. They also show how the dependent variable response causes changes in independent variables $[1,13]$. The maximum marginal effects of the individual probit method tend to be higher than the marginal effects of the bivariate probit method. This indicates that while another RM tool is used, then the effect of that influences the likelihood to adopt another RM tool [13]. Thus, the marginal effects estimates are reported in Table 5. The level of significance is high in marginal effects compared to the previous calculation.

For the contract farming equation in the bivariate probit approach, age and education are significant at $5 \%$ and $10 \%$ significance level, respectively, while the marginal effects of these variables are significant respectively at $1 \%$ and $5 \%$ significance levels. Likewise, in the precautionary savings equation of the bivariate probit model, observed heavy rains risk is at the $5 \%$ level of significance, while its marginal effect is significant at the $1 \%$ level in Table 5 . Another general insight from Table 5 
shows that the bivariate probit model is more significant for the marginal effects in comparison to the marginal effects drawn from individual probit method. Table 5 also reveals that the marginal effects of the bivariate probit approach are more significant than marginal effects from the individual probit approach. This suggests that the effects of the factors on the likelihood of adopting a risk management tool tend to be tempered when another risk management tool is already being used.

Table 5. Parameter estimations of marginal effects from bivariate and individual probit models.

\begin{tabular}{|c|c|c|c|c|}
\hline \multirow{2}{*}{ Independent Variables } & \multicolumn{2}{|c|}{ Bivariate Probit Model } & \multicolumn{2}{|c|}{ Individual Probit Model } \\
\hline & Contract Farming & Precautionary Savings & Contract Farming & Precautionary Savings \\
\hline \multicolumn{5}{|c|}{ Farm and socioeconomic characteristics } \\
\hline Age of farmer & $\begin{array}{c}0.0121 * * * \\
(0.0044)\end{array}$ & $\begin{array}{c}-0.0126^{* *} \\
(0.0049)\end{array}$ & $\begin{array}{c}0.0109 * * \\
(0.0043)\end{array}$ & $\begin{array}{c}-0.0107 * * \\
(0.0044)\end{array}$ \\
\hline Education of farmer & $\begin{array}{c}0.0151^{* *} \\
(0.0070)\end{array}$ & $\begin{array}{c}-0.0233^{* * * *} \\
(0.0077)\end{array}$ & $\begin{array}{l}0.0126^{*} \\
(0.0071)\end{array}$ & $\begin{array}{c}-0.0217^{* * * *} \\
(0.0071)\end{array}$ \\
\hline Farming year & $\begin{array}{c}-0.0133^{* * *} \\
(0.0043)\end{array}$ & $\begin{array}{c}0.0055 \\
(0.0049)\end{array}$ & $\begin{array}{c}-0.0133^{* * * *} \\
(0.0045)\end{array}$ & $\begin{array}{c}0.0037 \\
(0.0045)\end{array}$ \\
\hline Household income & $\begin{array}{l}0.00002^{* * *} \\
(0.0000003)\end{array}$ & $\begin{array}{l}0.00009^{* * *} \\
(0.000001)\end{array}$ & $\begin{array}{l}0.00003^{* * * *} \\
(0.0000005)\end{array}$ & $\begin{array}{l}0.00001 \text { *** } \\
(0.000001)\end{array}$ \\
\hline Family size & $\begin{array}{l}0.0066 \\
(0.0091)\end{array}$ & $\begin{array}{l}-0.0063 \\
(0.0101)\end{array}$ & $\begin{array}{c}0.0060 \\
(0.0094)\end{array}$ & $\begin{array}{l}-0.0054 \\
(0.0095)\end{array}$ \\
\hline Farm size & $\begin{array}{l}-0.0490 * \\
(0.0255)\end{array}$ & $\begin{array}{c}0.0374 \\
(0.0247)\end{array}$ & $\begin{array}{c}-0.0443^{*} \\
(0.0259)\end{array}$ & $\begin{array}{c}0.0323 \\
(0.0237)\end{array}$ \\
\hline Land ownership & $\begin{array}{c}0.2593^{* * *} \\
(0.0691)\end{array}$ & $\begin{array}{c}0.2384^{* * *} \\
(0.0701)\end{array}$ & $\begin{array}{c}0.2989 * * * \\
(0.0657)\end{array}$ & $\begin{array}{c}0.2329^{* * *} \\
(0.0613)\end{array}$ \\
\hline \multicolumn{5}{|c|}{ Risk perception } \\
\hline Risk of floods & $\begin{array}{c}0.1247 \\
(0.0681)\end{array}$ & $\begin{array}{c}0.2589 \\
(0.0670)\end{array}$ & $\begin{array}{c}0.0959 \\
(0.0721)\end{array}$ & $\begin{array}{c}0.2333 \\
(0.0613)\end{array}$ \\
\hline Risk of heavy rains & $\begin{array}{l}-0.0749 \\
(0.0689)\end{array}$ & $\begin{array}{c}0.1800 \\
(0.0890)\end{array}$ & $\begin{array}{l}-0.0549 \\
(0.0719)\end{array}$ & $\begin{array}{c}0.1599 \\
(0.0639)\end{array}$ \\
\hline Risk of pest and diseases & $\begin{array}{c}0.0459 \\
(0.0740)\end{array}$ & $\begin{array}{l}-0.2118 \\
(0.0671)\end{array}$ & $\begin{array}{c}0.0801 \\
(0.0729)\end{array}$ & $\begin{array}{l}-0.2069 \\
(0.0619)\end{array}$ \\
\hline Risk of drought & $\begin{array}{c}0.0743 \\
(0.0679)\end{array}$ & $\begin{array}{c}0.0089 \\
(0.0090)\end{array}$ & $\begin{array}{c}0.0539 \\
(0.0707)\end{array}$ & $\begin{array}{c}0.0087 \\
(0.0065)\end{array}$ \\
\hline Risk of heavy winds & $\begin{array}{c}0.0733 \\
(0.0677)\end{array}$ & $\begin{array}{l}-0.1799 \\
(0.0879)\end{array}$ & $\begin{array}{c}0.0529 \\
(0.0709)\end{array}$ & $\begin{array}{l}-0.1601 \\
(0.0641)\end{array}$ \\
\hline Risk of hailstorm & $\begin{array}{l}-0.0313 \\
(0.0121)\end{array}$ & $\begin{array}{c}0.8990 \\
(0.0701)\end{array}$ & $\begin{array}{l}-0.0219 \\
(0.0109)\end{array}$ & $\begin{array}{c}0.9011 \\
(0.0719)\end{array}$ \\
\hline \multicolumn{5}{|c|}{ Risk attitude } \\
\hline Risk aversion & $\begin{array}{c}0.2959 \\
(0.0915)\end{array}$ & $\begin{array}{c}0.3363 \\
(0.0659)\end{array}$ & $\begin{array}{c}0.3447 \\
(0.0779)\end{array}$ & $\begin{array}{c}0.3469 \\
(0.0553)\end{array}$ \\
\hline
\end{tabular}

Total Sample size $\quad 350$

Figures in parenthesis are standard errors. ${ }^{*}, * *$, and ${ }^{* * *}$ represent respectively statistical significance at 10,5 , and 1 percent level.

\subsection{Results of Multinomial Probit Models}

In this study, we have considered contract farming and precautionary savings as two RM management tools which comprise four different RM arrangements. There is a possibility of utilization of more than one RM tool, or combined use of risk-reducing tools simultaneously by farmers. Producers have to pick just one arrangement among the four. The different combinations from Table 1 are used as dependent variables in the multinomial probit model. The dependent variable is coded in such a way that $Y_{i}=1, \ldots, 4$ and only one arrangement (of the four) is selected by the producer. Table 6 represents the estimations of the parameters from the multinomial probit model. The results obtained from the multinomial probit model are different from the bivariate probit model due to producers' consideration of the factors affecting the arrangement of RM tools. Without age, monthly income, and education in the equation of precautionary savings, the noteworthy variables are same for both (bivariate probit and multinomial probit) models, which indicates the robustness of results. Also, except for farm 
size and land ownership, the parameter symbols are equally parallel in both methodologies. For the precautionary savings equation, farm size is positive in the bivariate model, although it is negative in the multinomial model, and reverse for land ownership. The factors encouraging contract farming adoption are risk perception of pests and diseases, drought, and wind, which is similar to the bivariate and individual probit model, except for flooding. Regarding precautionary savings, the most important factors are flooding, heavy rain, and pest-diseases, where flood and heavy rain is similar to the bivariate model but different in case of drought and hailstorm. Moreover, the factors encouraging the use of combination 4 are monthly income, land ownership, the risk of pests and diseases, hailstorms, and risk-averse nature of farmers. Age, family size, farm size, and risk of flood contribute to farmer's decisions of adopting combination 4; however, the effect of these variables is insignificant. Notably, in this case, causal identification is difficult. It is unclear whether contract farming increases farmers' precautionary savings and vice versa. As discussed by Bellemare and Bloem (2018), participation in contract farming is endogenous because both growers and processors choose whether to contract each other [66]. Therefore, our results only indicate that choosing one RM may result in another RM choice.

Table 6. Multinomial probit model estimates.

\begin{tabular}{|c|c|c|c|}
\hline Independent Variables & Contract Farming & Precautionary Savings & Both Contract Farming and Precautionary Savings \\
\hline \multicolumn{4}{|c|}{ Farm and socioeconomic characteristics } \\
\hline Age of farmer & $\begin{array}{c}0.0489^{* * *} \\
(0.0173)\end{array}$ & $\begin{array}{l}-0.0241 \\
(0.0249)\end{array}$ & $\begin{array}{c}0.0039 \\
(0.0209)\end{array}$ \\
\hline Education of farmer & $\begin{array}{l}0.0729 * * \\
(0.0289)\end{array}$ & $\begin{array}{l}-0.0401 \\
(0.0388) \\
\end{array}$ & $\begin{array}{l}-0.0451 \\
(0.0319) \\
\end{array}$ \\
\hline Farming year & $\begin{array}{c}-0.0329 * * \\
(0.0158)\end{array}$ & $\begin{array}{c}0.0221 \\
(0.0239)\end{array}$ & $\begin{array}{l}-0.0313 \\
(0.0199)\end{array}$ \\
\hline Household income & $\begin{array}{c}0.00003 * * * \\
(0.00001)\end{array}$ & $\begin{array}{c}0.00002 * * * \\
(0.00001)\end{array}$ & $\begin{array}{c}0.00007^{* * *} \\
(0.00001)\end{array}$ \\
\hline Family size & $\begin{array}{c}0.0133 \\
(0.0369) \\
\end{array}$ & $\begin{array}{l}-0.0107 \\
(0.0489)\end{array}$ & $\begin{array}{c}0.0149 \\
(0.0430)\end{array}$ \\
\hline Farm size & $\begin{array}{l}-0.2581 * * \\
(0.1099)\end{array}$ & $\begin{array}{l}-0.0148 \\
(0.1179)\end{array}$ & $\begin{array}{c}0.0271 \\
(0.1080)\end{array}$ \\
\hline Land ownership & $\begin{array}{l}0.7873^{* * *} \\
(0.2877)\end{array}$ & $\begin{array}{c}-0.6610 * * \\
(0.3360)\end{array}$ & $\begin{array}{l}1.6499 * * * \\
(0.3201)\end{array}$ \\
\hline \multicolumn{4}{|c|}{ Risk perception } \\
\hline Risk of floods & $\begin{array}{l}-0.3199 \\
(0.2889)\end{array}$ & $\begin{array}{c}0.7079 \\
(0.3850)\end{array}$ & $\begin{array}{c}0.4549 \\
(0.3299)\end{array}$ \\
\hline Risk of heavy rains & $\begin{array}{l}-0.3109 \\
(0.2859) \\
\end{array}$ & $\begin{array}{c}1.6699 \\
(0.4569) \\
\end{array}$ & $\begin{array}{l}-0.1099 \\
(0.3041) \\
\end{array}$ \\
\hline Risk of pest and diseases & $\begin{array}{c}0.5809 \\
(0.2969)\end{array}$ & $\begin{array}{c}1.1480 \\
(0.3409)\end{array}$ & $\begin{array}{c}0.7310 \\
(0.3210)\end{array}$ \\
\hline Risk of drought & $\begin{array}{c}0.1720 \\
(0.4999)\end{array}$ & $\begin{array}{l}-0.0841 \\
(0.6961)\end{array}$ & $\begin{array}{l}-0.0701 \\
(0.5269)\end{array}$ \\
\hline Risk of heavy winds & $\begin{array}{c}0.4069 \\
(0.5399)\end{array}$ & $\begin{array}{l}-0.6829 \\
(0.8969)\end{array}$ & $\begin{array}{l}-0.1901 \\
(0.5658)\end{array}$ \\
\hline Risk of hailstorm & $\begin{array}{l}-0.1816 \\
(0.4670)\end{array}$ & $\begin{array}{l}-0.3309 \\
(0.6449)\end{array}$ & $\begin{array}{c}0.2730 \\
(0.4889)\end{array}$ \\
\hline \multicolumn{4}{|c|}{ Risk attitude } \\
\hline Risk aversion & $\begin{array}{c}0.7730 \\
(0.3399)\end{array}$ & $\begin{array}{c}0.8919 \\
(0.4031)\end{array}$ & $\begin{array}{c}2.5839 \\
(0.4620)\end{array}$ \\
\hline Log-likelihood value & -329.5451 & & \\
\hline Total Sample size & 350 & & \\
\hline
\end{tabular}

\section{Conclusions}

In modern times, there are several options for managing agricultural risks. Agricultural producers use several RM strategies simultaneously. However, most previous studies have ignored the correlation 
between farmers' adoption of RM tools and prospects of using RM tools simultaneously. Therefore, this study was designed to investigate the impact of farm and farm characteristics, as well as farmers' perceptions of different risks, and their risk attitudes in making decisions about the two selected RM tools-contract farming and precautionary savings. The current research work also describes the link between farmers' decisions for adopting the two RM tools through bivariate and multinomial probit methods.

The results of this study confirm the correlation between farmers' adoption of contract farming and precautionary savings in order to manage farm risks. It also concluded that the adoption of one RM tool would encourage farmers to use another RM tool simultaneously. The results indicate the significance of household head's age and education, the experience of farming, monthly income, and ownership of land, and the influence of risk-averse attitudes of farmers on their decisions in adopting RM tools. However, we recognize that the existence of reverse causal relationships may lead to estimation bias. Although the study covers only four districts of Bangladesh, the results can be generalized in the contexts of all developing countries, specifically in countries where formal RM tools such as crop insurance are ineffective or absent. By analyzing RM choices, it can be understood that better explanations, better speculation, and additional factors which could develop the acceptance of farmer's RM choices can be provided through both of bivariate and multinomial probit methods. The information provided in this study will help the government understand farmers' risk behaviors and develop better policies for farmers to improve the performance of risks management tools. The results of this study will help stakeholders who need information to devise better RM tools for minimizing farming risks.

Future research will also benefit from this study as it helps to identify the different sources of risk typically associated with agricultural crops, especially considering the occurrence of different sources of risk and the accompanying problems. The government should make necessary arrangements for conducting training programs through developed extension services for spreading awareness with respect to the adoption of crop insurance as the main risk-reducing tool.

Author Contributions: Conceptualization, K.M.M.A., L.Y., and S.A.S. Data collection, K.M.M.A. and S.A.S. Formal analysis, K.M.M.A. and M.H. Funding acquisition, L.Y. Investigation, K.M.M.A. and S.A.S. Methodology, K.M.M.A., M.H, A.R., and L.Y. Project administration, K.M.M.A. and L.Y. Resources, L.Y. Software, K.M.M.A., M.H.R. and S.A.S. Validation, S.A.S. Visualization, L.Y.; Writing-original draft, K.M.M.A. Writing-review and editing, M.H., K.M.M.A., L.Y., S.A.S., A.R., and M.H.R.

Funding: This work was supported by the Fundamental Research Funds for the Central Universities (Program No. 2662017PY062).

Acknowledgments: The authors give thanks the farmers who give their time and data for completing this research. All caveats remain with the author.

Conflicts of Interest: The authors declare no conflict of interest.

\section{References}

1. Ullah, R.; Jourdain, D.; Shivakoti, G.P.; Dhakal, S. Managing catastrophic risks in agriculture: Simultaneous adoption of diversification and precautionary savings. Int. J. Disaster Risk Reduct. 2015, 12, $268-277$. [CrossRef]

2. Hardaker, J.B.; Huirne, R.B.M.; Anderson, J.R.; Lien, G. Coping with Risk in Agriculture, 2nd ed.; CABI: Wallingford, UK, 2004; p. 332.

3. Mishra, A.K.; Sandretto, C.L. Stability of farm income and the role of nonfarm income in U.S. Agriculture. Rev. Agric. Econ. 2002, 24, 208-221. [CrossRef]

4. Mishra, A.K.; El-Osta, H.S.; Sandretto, C.L. Factors affecting farm enterprise diversification. Agric. Financ. Rev. 2004, 64, 151-166. [CrossRef]

5. Moschini, G.; Hennessy, D.A. Uncertainty, Risk Aversion and Risk Management for Agricultural Producers; Lowa State University Economic Staff Paper Series; Lowa State University: Ames, IA, USA, 1999; p. 315.

6. Drollette, S.A. Managing production risk in agriculture. In AG/ECON/2009-03RM; Department of Applied Economics Utah State University, Ed.; Utah State University: Logan, UT, USA, 2009. 
7. Ullah, R.; Shivakoti, G.P.; Kamran, A.; Zulfiqar, F. Farmers versus nature: Managing disaster risks at farm level. Nat. Hazards 2016, 82, 1931-1945. [CrossRef]

8. Singla, S. Integrated risk management in agriculture: An inductive research. J. Risk Financ. 2012, 13, $199-214$. [CrossRef]

9. Kammar, S.K.; Bhagat, R. Constraints experienced by farmers in adopting risk and uncertainty management strategies in rainfed agriculture. Pusa Agriscience 2009, 32, 70-74.

10. Musser, W.N.; Patrick, G.F. How Much Does Risk Really Matter to Farmers? Springer: Boston, MA, USA, 2002; Volume 23.

11. Kahan, D. Managing Risk in Farming; FAO (Food and Agriculture Organization of the United Nations): Rome, Italy, 2013.

12. Mishra, A.; El-Osta, H. Risk management through enterprise diversification: A farm-level analysis. In Proceedings of the 2002 AAEA Meetings, Long Beach, CA, USA, 28-31 July 2002.

13. Velandia, M.; Rejesus, R.M.; Knight, T.O.; Sherrick, B.J. Factors affecting farmers' utilization of agricultural risk management tools: The case of crop insurance, forward contracting, and spreading sales. J. Agric. Appl. Econ. 2009, 41, 107-123. [CrossRef]

14. USDA. United States Department of Agriculture Agricultural Research Service; USDA Food Composition Databases: Beltsville, MD, USA, 2017.

15. BBS. Statistical Yearbook of Bangladesh 2017; Government People's Republic of Bangladesh: Dhaka, Bangladesh, 2017.

16. Haque, T. Contractual arrangements in land and labour markets in rural India. Indian J. Agric. Econ. 2000, 55, 233.

17. Baumann, P. Equity and Efficiency in Contract Farming Schemes: The Experience of Agricultural Tree Crops; Overseas Development Institute: London, UK, 2000; Volume 111.

18. Covey, T.D. Analysis of the Rough Rice Futures Contract; Agricultural Economics Research Report; Mississippi Agricultural and Forestry Experiment Station (USA): Bost North, MS, USA, 1985.

19. Martinez, S. Vertical Coordination of Marketing Systems: Lessons from the Poultry, Egg, and Pork Industries; United States Department of Agriculture Agricultural Economic Report No. 807; United States Department of Agriculture: Beltsville, MD, USA, 2002.

20. Kirsten, J.; Sartorius, K. Linking agribusiness and small-scale farmers in developing countries: Is there a new role for contract farming? Dev. South. Afr. 2002, 19, 503-529. [CrossRef]

21. Eaton, C.; Shepherd, A. Contract Farming: Partnerships for Growth; Food \& Agriculture Organization: Rome, Italy, 2001.

22. Prescott, E.S.; Townsend, R.M. Collective organizations versus relative performance contracts: Inequality, risk sharing, and moral hazard. J. Econ. Theory 2002, 103, 282-310. [CrossRef]

23. Ullah, R.; Shivakoti, G.P.; Rehman, M.; Kamran, M.A. Catastrophic risks management at farm: The use of diversification, precautionary savings and agricultural credit. Pak. J. Agric. Sci. 2015, 52.

24. Hess, U.; Skees, J.; Stoppa, A.; Barnett, B.; Nash, J. Managing Agricultural Production Risk: Innovations in Developing Countries; Agriculture and Rural Development (ARD) Department Report; THE WORLD BANK: Washington, DC, USA, 2005.

25. Dadzie, S.K.N.; Acquah, H. Attitudes toward risk and coping responses: The case of food crop farmers at agona duakwa in agona east district of ghana. Int. J. Agric. For. 2012, 2, $29-37$.

26. Bar-Shira, Z.; Just, R.E.; Zilberman, D. Estimation of farmers' risk attitude: An econometric approach. Agric. Econ. 1997, 17, 211-222. [CrossRef]

27. Ullah, R.; Shivakoti, G.P.; Ali, G. Factors effecting farmers' risk attitude and risk perceptions: The case of khyber pakhtunkhwa, pakistan. Int. J. Disaster Risk Reduct. 2015, 13, 151-157. [CrossRef]

28. Greiner, R.; Patterson, L.; Miller, O. Motivations, risk perceptions and adoption of conservation practices by farmers. Agric. Syst. 2009, 99, 86-104. [CrossRef]

29. Wan-rong, G.; Yi, J.; Yao, M.; Jian-guo, W.; Xian-long, Z.; Jing, L.; Shi, W. Swot analysis and development strategies of maize industry in heilongjiang province. J. Northeast Agric. Univ. (Engl. Ed.) 2013, 20, 76-84. [CrossRef]

30. Hossain, T. Gain report number: Bg 1803. Global Agricultural Informaion Network, USDA Forien Agricultural Services; USDA: Beltsville, MD, USA, 2018. 
31. Hasan, M.F. Economic efficiency and constraints of maize production in the northern region of Bangladesh. J. Innov. Dev. Strategy 2008, 2, 18-22.

32. Sharmistha, B.; Razib, B.; Sharmistha, G. Reviewing the status of agricultural production in Bangladesh from a food security perspective. Russ. J. Agric. Socio-Econ. Sci. 2014, 25, 19.

33. Buresh, D.R. Sustainable Intensification of Rice-Maize Production Systems in Bangladesh; Australian Centre for International Agricultural Research: Canberra, Australia, 2013; CIM/2007/122.

34. Harwood, J.L.; Heifner, R.; Coble, K.; Perry, J.; Somwaru, A. Managing Risk in Farming: Concepts, Research, and Analysis; US Department of Agriculture, Economic Research Service: Beltsville, MD, USA, 1999.

35. Hope, J.; Lingard, J. The influence of risk aversion on the uptake of set-aside: A motad and crp approach. J. Agric. Econ. 1992, 43, 401-411. [CrossRef]

36. Bastian, C.; Held, L. Enterprise diversification: Will it reduce your risk? Article 1999, 2, 1-6.

37. Kouamé, E.B.-H. Risk, risk aversion and choice of risk management strategies by cocoa farmers in western cote d'ivoire. University of Cocody-AERC Collaborative PHD Program. 2010. Available online: http: / / www.csae.ox.ac.uk/conferences/2010-EDiA/papers /267-Kouame.pdf (accessed on 2 October 2018).

38. Sherrick, B.J.; Barry, P.J.; Ellinger, P.N.; Schnitkey, G.D. Factors influencing farmers' crop insurance decisions. Am. J. Agric. Econ. 2004, 86, 103-114. [CrossRef]

39. Tanaka, T.; Camerer, C.F.; Nguyen, Q. Risk and time preferences: Linking experimental and household survey data from vietnam. Am. Econ. Rev. 2010, 100, 557-571. [CrossRef]

40. Harrison, G.W.; Lau, M.I.; Rutström, E.E. Estimating risk attitudes in denmark: A field experiment. Scand. J. Econ. 2007, 109, 341-368. [CrossRef]

41. Cohen, A.; Einav, L. Estimating risk preferences from deductible choice. Am. Econ. Rev. 2007, 97, 745-788. [CrossRef]

42. Ayinde, O. Effect of socio-economic factors on risk behaviour of farming households: An empirical evidence of small-scale crop producers in kwara state. Nigeria Agric. J. 2008, 3, 447-453.

43. Kisaka-Lwayo, M.; Obi, A. Risk perceptions and management strategies by smallholder farmers in kwazulu-natal province, south africa. Int. J. Agric. Manag. 2012, 1, 28-39.

44. Lucas, M.P.; Pabuayon, I.M. Risk perceptions, attitudes, and influential factors of rainfed lowland rice farmers in ilocos norte, philippines. Asian J. Agric. Dev. 2011, 8, 61.

45. Makus, L.D.; Lin, B.H.; Carlson, J.; Krebill-Prather, R. Factors influencing farm level use of futures and options in commodity marketing. Agribusiness 1990, 6, 621-631. [CrossRef]

46. Ortmann, G.; Patrick, G.; Musser, W.; Doster, D. Sources and management of risk: Evidence from leading cornbelt farmers in the USA/broone en bestuur van risiko: Bewyse van vooraanstaande 'cornbelt'-boere in die vsa. Agrekon 1992, 31, 216-221. [CrossRef]

47. Zulfiqar, F.; Ullah, R.; Abid, M.; Hussain, A. Cotton production under risk: A simultaneous adoption of risk coping tools. Nat. Hazards 2016, 84, 959-974. [CrossRef]

48. Cooper, D.F. Project Risk Management Guidelines: Managing Risk in Large Projects and Complex Procurements; John Wiley \& Sons, Inc.: Hoboken, NJ, USA, 2005.

49. Hammer, T.F.; Rosenberg, L. Continuous risk management at NASA. In Proceedings of the 1999 Applied Software Measurement/Software Management Conference, San Jose, CA, USA, February 1999; Available online: http:/ / www.lomag-man.org/gestiondurisque/riskmanagement/ContRsk1nasa.pdf (accessed on 2 October 2018).

50. Binici, T.; Koc, A.A.; Zulauf, C.R.; Bayaner, A. Risk attitudes of farmers in terms of risk aversion: A case study of lower seyhan plain farmers in adana province, turkey. Turk. J. Agric. For. 2003, 27, 305-312.

51. Pratt, J.W. Risk aversion in the small and in the large. In Stochastic Optimization Models in Finance; Elsevier: Amsterdam, The Netherlands, 1975; pp. 115-130.

52. Arrow, K.J. The role of securities in the optimal allocation of risk-bearing. Rev. Econ. Stud. 1964, 31, 91-96. [CrossRef]

53. Olarinde, L.; Manyong, V.; Akintola, J. Attitudes towards risk among maize farmers in the dry savanna zone of nigeria: Some prospective policies for improving food production. Afr. J. Agric. Res. 2007, 2, 399-408.

54. Ullah, R.; Shivakoti, G.P. Adoption of on-farm and off-farm diversification to manage agricultural risks: Are these decisions correlated? Outlook Agric. 2014, 43, 265-271. [CrossRef] 
55. Lu, W.; Latif, A.; Ullah, R. Simultaneous adoption of contract farming and off-farm diversification for managing agricultural risks: The case of flue-cured virginia tobacco in pakistan. Nat. Hazards 2017, 86, 1347-1361. [CrossRef]

56. Cahyadi, E.R.; Waibel, H. Is contract farming in the indonesian oil palm industry pro-poor? J. Southeast Asian Econ. 2013, 30, 62-76. [CrossRef]

57. Deressa, T.T.; Ringler, C.; Hassan, R.M. Factors Affecting the Choices of Coping Strategies for Climate Extremes; The Case of Farmers in the Nile Basin of Ethiopia IFPRI Discussion Paper; IFPRI: Washington, DC, USA, 2010; Volume 1032.

58. Wainaina, P.W.; Okello, J.J.; Nzuma, J. Impact of contract farming on smallholder poultry farmers' income in Kenya. In Proceedings of the Triennial Conference of International Association of Agricultural Economists, Foz do Iguacu, Brazil, 18-24 August 2012; Citeseer: London, UK; pp. 18-24.

59. Tavernier, E.M.; Onyango, B.M. Utilization of farm management risk strategies at the rural/urban fringe. Afr. J. Agric. Res. 2008, 3, 554-565.

60. Ashfaq, M.; Hassan, S.; Naseer, M.Z.; Baig, I.A.; Asma, J. Factors affecting farm diversification in rice-wheat. Pak. J. Agric. Sci. 2008, 45, 91-94.

61. Rehima, M.; Belay, K.; Dawit, A.; Rashid, S. Factors affecting farmers' crops diversification: Evidence from SNNPR, Ethiopia. Int. J. Agric. Sci. 2013, 3, 558-565.

62. Bellemare, M.F. As you sow, so shall you reap: The welfare impacts of contract farming. World Dev. 2012, 40, 1418-1434. [CrossRef]

63. Fawole, P.; Thomas, K.A. Effects of contract farming scheme on cassava production enterprise in oyo state, nigeria. J. Rural Econ. Dev. 2011, 20, 1-7.

64. Jensen, F.E.; Pope, R.D. Agricultural precautionary wealth. J. Agric. Resour. Econ. 2004, 29, 17-30.

65. Mishra, A.K.; Chang, H.-H. Factors affecting precautionary savings of self-employed farm households. Agric. Financ. Rev. 2009, 69, 300-313. [CrossRef]

66. Bellemare, M.F.; Bloem, J.R. Does contract farming improve welfare? A review. World Dev. 2018, 112, $259-271$. [CrossRef]

(C) 2018 by the authors. Licensee MDPI, Basel, Switzerland. This article is an open access article distributed under the terms and conditions of the Creative Commons Attribution (CC BY) license (http://creativecommons.org/licenses/by/4.0/). 